\title{
Business Architecture Model in Strategic Information System Management for Effective Railway Supply Chain Perspective
}

\author{
Mailasan Jayakrishnan', Abdul Karim Mohamad ${ }^{1}$, Mokhtar Mohd Yusof ${ }^{2}$ \\ ${ }^{I}$ Centre for Advanced Computing Technology, Faculty of Information \& Communication Technology, Universiti Teknikal \\ Malaysia Melaka, Hang Tuah Jaya, 76100, Durian Tunggal, Melaka, Malaysia \\ ${ }^{2}$ Faculty of Computer and Information Technology, Al-Madinah International University, Pusat Perdagangan Salak 2, No.18, \\ Jalan 2/125e, Taman Desa Petaling, 57100 Kuala Lumpur, Malaysia.
} ${ }^{1}$ ORCID: 0000-0002-7807-1621 (M. Jayakrishnan )

\begin{abstract}
Industry environments are increasingly complex and dynamic. Across the globe, strategic Information System (IS) management transformation is taking place. It is cutting across several sectors, organizations, processes, and industries. Continuous improvement in industry performance needs a Business Architecture (BA) model as a strategic imperative in their performance. BA underpins the usage of normalized management policy relevant to the turn of events and the use of IS and different assets. Once the BA instrument has been mapped with all the other rating and ranking systems, we will evaluate and propose an improved Railway Supply Chain (RSC) indicator. A draft of criteria, sub-criteria, and indicators will be developed based on the current need of the Railway Industry (RI). Strategic IS management may uphold the choices individuals make in each progression of a cycle that analyzes the sources of info, the time, and the yields for each progression of the cycle and helps distinguish the process bottlenecks. Therefore, we need a dynamic RSC perspective that posits a key enabler to the national agenda by developing an RSC model in BA. By giving a comprehensive, various leveled perspective on current and future assets RSC model in BA will support key arranging and other operational asset arranging measures by giving large-scale and miniature perspectives on how assets are to be utilized in achieving the objectives of the RI. Thus, we need to initiate the layout methodologies and an activity that intends to additionally build up the Malaysia RSC strategized decision-making process.
\end{abstract}

Keywords: Business Architecture, Information System, Supply Chain, Strategic Model, Railway Industry

\section{INTRODUCTION}

There exist several challenges or at least concerns, regarding the nature of what future architecture alignment is and what it may realistically be expected to achieve and do for the contemporary industry today. The future architecture model needed to be modified Business Architecture (BA) components that emphasize on existing execution hole or backing another vital activity, operational necessity, and innovation arrangement. The future architecture is driven at both the key and strategic levels in three perspectives as (1) new direction and objectives, (2) changing business needs, and (3) rising advancements. The future architecture should emphasis on systems approached to rehearse.

Tending to complex issues or openings utilizing strategies, devices, structures, and practice designs for the industry decision-making process [1]. The future architecture should cover arranged changes to BA segments in the close to term, just as changes to vital, IS parts that are resulted in the usage of long-haul working situations. BA facilitates gap analysis to understand why certain plans operate more efficiently than others [2]. Measuring the industry impact of BA can be difficult as performance improvements are attributable to factors beyond BA. There is an agreement among researchers and industry experts that the business domain and IS domain arrangement are essential to industry execution and the accomplishment of the upper hand [3].

The integration between business and IS needed to focus on hard and soft methods. The hard methods are fit to taking care of all around characterized issues with dependable information, clear optimization objectives, and realistic function. The soft methods are fit for organizing issues including deficient information, indistinct objectives, and complexity contents. Therefore, we need to choose the appropriate mix of hard and soft methods for heuristics industry performance evaluation. Over the years, there had been a developing worry of BA developments among Railway Supply Chain (RSC) [4]. There have a needs to recognize the status level of BA selection and use as valuable data and direction to related bodies for growing further procedures [5].

Early recognizable proof and advancement of BA is the way to limiting its negative impacts and to getting the RSC destined for success [6]. Besides, the early improvement of BA in RSC is a significant key to decreasing complex working models later on [2], [7]. The RSC indicators are an important element to encourage BA adoption and further contributed to usage. A good BA will portray the association both as it is today and as it is imagined later and will plan the different perspectives speaking to the design [8]. These perspectives incorporate both industry- situated points of view just as a specialized viewpoint [9]. In Canada, various degrees of RSC use BA to give structural surveys of key pointers and to organize the recognizable proof of new and basic parts and administrations inside the legislature [10].

Thus, BA similar to the conventional design in building development is a holistic body of information of the RSC indicators of a BA and their relationships [11]. The expanding of future architecture in the industry should focus on applying lean thinking in the transition to lean roadmap, enterprise transformation in knowledge exchange events, and BA action leadership in the IS context. Even though the context to which information ecology is applied differ, all the domain aim at effective implementation of strategize industry performance. 


\section{BUSINESS ARCHITECTURE MODEL}

Business Architecture (BA) is an administration and innovation practice that is committed to improving the presentation of the industry by empowering them to see themselves regarding a holistic and coordinated perspective on their key direction, strategic policies, data streams, and innovation assets [8], [12][14]. Recently, nations on the planet are moving from a mechanical economy to an information and computerized economy whereby the financial development is subject to a nation's capacity to make, amass and disperse information as revealed by Asia-Pacific Development Information Program, 2018 in China [15]. BA provides support for Information System (IS) asset dynamic at the executives, management, and operation levels of the industry [16]. In its most basic sense, BA provides executives data to recognize what is happening in the industry.

Industry execution is estimated by several financial pointers, for example, income, profitability, margin, and cost to serve [17]. At the executive level, BA gives perceived to huge IS activities and supports the assurance of key arrangement. The wave of BA that is capable of sending and preparing data is considered as a component of the data society that ready to make and spread new data [18]. BA allows the industry to boost revenues by cross-selling products to existing customers. BA touches everyone in the industry and beyond to customers and suppliers. BA upholds normalized approaches for directing the improvement of capacities and enhancing supporting assets [19]. Yet, BA is an emphasis on rating industry excellence in supply chain management.

The idea of looking at supply chain management through the $\mathrm{BA}$ rating is comprehensive and will not be too centric. At the administration level, BA underpins plan and arrangement management decisions, just as the arrangement of IS activities with specialized norms. BA is a vital data resource base, which characterizes the mission and the momentary cycle for executing new advancements considering the changing mission needs [20]. In this way, to contend in the information economy, the industry needs a solid BA aptitudes base that can enhance and adjust rapidly to meet the evolving. Once the BA instrument has been mapped with all the other rating and ranking systems, we will evaluate and propose an improved Railway Supply Chain (RSC) indicator. A draft of criteria, subcriteria, and indicators will be developed based on the current need of the Railway Industry (RI). Industry association particularly RSC in Malaysia should be a versatile venture which can react appropriately and promptly to changes in the industry environment [21].

BA is cultivated through an administration program and an examination and plan strategy that is repeatable at different degrees of extension. However, the BA program and technique give a progressing capacity and significant, composed perspectives on an industry vital course, industry administrations, data streams, and asset usage. The industry must be truly outstanding in their performance to fulfill the strategic roles required by the BA transformational journey. Specifically, industry strategy includes developing a competent and passionate supplier, grooming executives' mentors, and nurturing leaders who have a passion for industry development work. BA a continuous administration concept that gives a vital, coordinated way to deal with ability and asset getting ready for dynamic. Therefore, we have tabulated the BA model for a high-level strategic view from an industry perspective, as shown in Table 1.

Table 1. Business Architecture Model for High-Level Strategic View

\begin{tabular}{|c|c|c|c|c|}
\hline Model Alignment & Business Architecture Indicators & $\begin{array}{c}\begin{array}{c}\text { High-Level Strategic } \\
\text { View }\end{array} \\
\end{array}$ & Industry Management & $\begin{array}{l}\text { Strategic Information } \\
\text { System Management }\end{array}$ \\
\hline $\begin{array}{c}\text { High-level } \\
\text { strategies } \\
\text { Strategy Level } \\
\text { (Strategic objectives) }\end{array}$ & $\begin{array}{c}\text { Strategic Alignment } \\
\text { (Strategy causal and effect) }\end{array}$ & $\begin{array}{l}\text { Where is the industry } \\
\text { and where does the } \\
\text { industry is going? }\end{array}$ & $\begin{array}{l}\text { Connects resources, } \\
\text { goals, and activities }\end{array}$ & $\begin{array}{l}\text { The model, design, } \\
\text { analysis, and artifact set. }\end{array}$ \\
\hline $\begin{array}{c}\text { Competitive } \\
\text { Research } \\
\text { Business Level } \\
\text { (Business result) }\end{array}$ & $\begin{array}{l}\text { Planning Policy } \\
\begin{array}{l}\text { (Establish interfacing hub to facilities } \\
\text { industry development) }\end{array}\end{array}$ & $\begin{array}{c}\text { How will the industry } \\
\text { get there? }\end{array}$ & $\begin{array}{l}\text { Resource } \\
\text { implementation and } \\
\text { governance. }\end{array}$ & $\begin{array}{l}\text { Views of as-is strategies, } \\
\text { resources, and processes. }\end{array}$ \\
\hline 司橾 & $\begin{array}{c}\text { Execution Decision } \\
\text { (Increase knowledge transfer to the industry) }\end{array}$ & $\begin{array}{l}\text { What should each } \\
\text { effort look like? }\end{array}$ & $\begin{array}{l}\text { Configuration } \\
\text { management and } \\
\text { financial control. }\end{array}$ & $\begin{array}{l}\text { Views of to-be strategies, } \\
\text { resources, and processes. }\end{array}$ \\
\hline \begin{tabular}{c|} 
Total Online \\
Presence Audit \\
Technology Level \\
(Technology Process)
\end{tabular} & \begin{tabular}{|lll|}
\multicolumn{4}{|c|}{ Value-Oriented } \\
(Strengthen & strategic linkages & between \\
industries)
\end{tabular} & $\begin{array}{l}\text { What is the traceable } \\
\text { outcome of the } \\
\text { industry? }\end{array}$ & $\begin{array}{l}\text { The dynamic approach } \\
\text { to management and } \\
\text { development. }\end{array}$ & $\begin{array}{l}\text { An arrangement to move } \\
\text { from the current to a } \\
\text { future value oriented. }\end{array}$ \\
\hline
\end{tabular}


Based on Table 1 the BA model for high-level strategic view establishes an integrating hub that facilitates industry development. Through this hub, the industry will be able to enhance knowledge transfer. This would mean the industry will be able to create decisions for the suppliers through the technology decision-making process. Without any doubt, it is imperative to strengthen linkages with the industry and the supplier, for the benefit of the community. Through this integration, it is expected that the supply chain shall be obtained to support the community's needs. Among the key areas that the industry will focus on are the BA model and strategic Information System (IS) management for the suppliers. Railway Industry (RI) is a strategic industry to enhance the well-being of the local supplier taking advantage of the industry.

Nonetheless, it cannot be denied that there are critical enablers for those strategies to be successfully implemented., where industry able to lead and make a positive change to the community. Knowledge transfer that can produce impactful and useful industry solutions and an excellent IS structure that is well equipped with technology and facilities to increase interaction among industries. Thus, BA makes a substantial difference and contribution to industry performance by demonstrating the highest level of potential. Besides BA refers to the creation of a systematic ecosystem that can attract, identify, develop, engage, retain, and deploy industry who encounter market functions to contribute to industry strategic direction and long-term goals.

This enabler BA model to ensure that all the high-level strategic view is recruited from industry sources, carefully observe to enhance supply chain and productivity, and to make the industry the highest level. The strategic BA model needs to realize RI goals in qualified and well-trained subject matter experts in Railway Supply Chain (RSC), innovative and creative industry experts in RI focus areas, skillful and experienced mentors in the field of RSC, and a passionate workforce that consistently take the lead in the RI development. With the three-core BA model alignment identified to move RI to a higher position in RSC, the RI must be ready to forge forward and make the necessary adjustment and change.

\section{STRATEGIC INFORMATION SYSTEM MANAGEMENT}

While early IS organizations centered more around vital choice everyday activities of the industry. In such a manner, getting too detailed information and surveying data may be important to and execution, IS increasing assumes a basic part in the

finish an assignment [22]. Across the globe, strategic IS management transformation is taking place [23]. It is cutting across several sectors, organizations, processes, and industries. Approaching toward information assortment and investigation with IS mind that can focus endeavors on the measurements matter. The best industry is laser-centered around what they are attempting to accomplish with strategic IS management and they have achievement gauges that are express and straightforward. Operational IS most varies from IS for control and management purposes in both the degree of detail required and in the timelines of the information [24].

Strategic IS management should provide a holistic perspective on current and future assets through recognizing key and operational necessities, the key arrangement of exercises and assets, creating BA and overseeing the management context, identifying performance metrics and standards for IS management. It is depicted that a strategic IS perspective is imperative to drive the industry outcome. Nonetheless, it cannot be denied that there are critical enablers for those strategies to be successfully implemented. Competent IS though industry development is the responsibility of executives, the team of decision-makers must drive IS strategies and pro-actively innovate in the efforts to manage the strategic decision-making process.

Satisfactory IS infrastructure and facilities refer to industry development facilities, unique to the decision-making set of the strategic outcome. Sustainable IS support must separate operational from strategic outcomes where later it supports strategic management, beyond the normal and statutory industry resource development processes [25]. Its emphasis on the strategic and intellectual dimension that has a BA plan for a holistic encompassing of current or future industry needs, where IS is probably going to get various and unequipped for scaling after some time. Present industry connections are perplexing, including a mix of suppliers and other third parties.

Therefore, strategic IS management need to align for these relationships for improving the operational efficiency with a consequent competitive advantage. IS upholds the utilization of a normalized cycle for choosing and assessing the interest in BA assets from a business and monetary point of view. Moreover, IS underpins choices concerning tasks, upkeep, and the improvement of BA assets in the RI context. Thus, we need to understand the evolution of IS for designing the baseline of current and future value drivers in the industry for competitive advantage, as appeared in Table 2 .

Table 2. Evolution of Strategic Information System Management Value Drivers

\begin{tabular}{|c|c|c|c|}
\hline $\begin{array}{c}\text { Evolution of } \\
\text { Information System }\end{array}$ & Justification Perspective & Strategic Management & \multicolumn{1}{c|}{ Value Drivers } \\
\hline $\begin{array}{c}\text { Aware } \\
\text { (Process-an } \\
\text { incorporated and } \\
\text { proficient arrangement } \\
\text { of cycles and } \\
\text { exercises) }\end{array}$ & $\begin{array}{c}\text { A beginning phase of an investigation } \\
\text { that expects to demonstrate the } \\
\text { estimation of computerization devices in } \\
\text { a restricted extension before focusing on } \\
\text { more extensive usage. }\end{array}$ & $\begin{array}{c}\text { Focused on cost reduction } \\
\text { and capacity generation. }\end{array}$ & $\begin{array}{l}\text { Essential, restricted computerization } \\
\text { abilities are sent in silos. }\end{array}$ \\
\hline
\end{tabular}




\begin{tabular}{|c|c|c|c|}
\hline $\begin{array}{l}\text { Developing } \\
\text { (Technology-the } \\
\text { technology } \\
\text { architecture, software, } \\
\text { and hardware with } \\
\text { required tools) }\end{array}$ & $\begin{array}{l}\text { The industry is looking past cost } \\
\text { decrease however faces huge difficulties } \\
\text { in accomplishing the full worth and } \\
\text { expected advantages. }\end{array}$ & $\begin{array}{l}\text { Extend to the decrease of } \\
\text { mistakes and empowering } \\
\text { development without } \\
\text { developing cost-base. }\end{array}$ & $\begin{array}{l}\text { Further appropriation of advanced } \\
\text { robotics with restricted scale in different } \\
\text { zones and point arrangements created } \\
\text { utilizing intellectual capacities. }\end{array}$ \\
\hline $\begin{array}{l}\text { Practicing } \\
\text { (Integration-clear } \\
\text { roles, decision rights } \\
\text { and policies) }\end{array}$ & $\begin{array}{l}\text { Diverting the corner from creating to } \\
\text { rehearsing includes accomplishing the } \\
\text { guarantee of the technologies, which } \\
\text { means making more sensible business } \\
\text { cases that unequivocally connect the } \\
\text { worth drivers. }\end{array}$ & $\begin{array}{l}\text { Expand to revenue growth } \\
\text { and enhancing customer } \\
\text { experience in selected } \\
\text { areas. }\end{array}$ & $\begin{array}{l}\text { Industry outcome led through robotics at } \\
\text { scale in various arrangements utilizing the } \\
\text { business to tackle the business issues. }\end{array}$ \\
\hline $\begin{array}{l}\text { Leading } \\
\text { (Insights-the decision } \\
\text { flow, information, and } \\
\text { analytics) }\end{array}$ & $\begin{array}{l}\text { Generally, includes a settled } \\
\text { robotization program with an interior } \\
\text { utilizing innovation that centers around } \\
\text { change to improve start to finish } \\
\text { measures over the business. }\end{array}$ & $\begin{array}{l}\text { Extend to utilizing } \\
\text { metadata to develop a } \\
\text { perspective on the activity, } \\
\text { empowering further worth } \\
\text { creation, and catch. }\end{array}$ & $\begin{array}{l}\text { Industry adoption that arranged } \\
\text { robotization with associated endeavors } \\
\text { across computerized, intellectual, and } \\
\text { robotics that has cross-chain of command } \\
\text { activities for the business-based age of } \\
\text { arrangements at scale. }\end{array}$ \\
\hline
\end{tabular}

Based on Table 2, the evolution of strategic IS management value drivers focus on aware in selecting the correct cycles that is fundamental to short and long haul accomplishment in likely incentive to the industry and level of intricacy through targeting on the high worth that lines up with industry needs and worth drivers, developing through establishing the technology architecture that becomes an integral part of the industry processes and a clear plan to efficiently update industry changes, practicing in integration on an administration system that underpins an organized methodology over the industry lifecycle to accomplish the normal outcomes and set up clear jobs and duties and set desires for the industry context and leading in insight through capturing an abundance of new data about industry measures that can uphold main driver investigation, esteem attribution and other key goals on the metrics that highlights the value of the data for the strategic decision-making process.

\section{DYNAMIC RAILWAY SUPPLY CHAIN PERSPECTIVE}

For many years, the supply chain was an operational issue that didn't merit a lot of consideration [26]. Executives started searching for enhancements to the supply chain, they began with independent exercises, for example, procurement, stock control, warehousing, transport, materials taking care of, and bundling. Executives have experience in the competitive arena where rivals seek to take their market share. Yet this view of strategy often yields poor results because strategy gets defines and measured in terms of the competition. Still, it before long turns out to be certain that these are not particular exercises that can be taken care of in detachment and any change to one influences the others.

Besides the recognition, the supply chain is a basic capacity that needs cautious administration that strategically impact on the industry performance and value chain. RI now represents $97 \%$ or 645,000 establishments of the total establishment of 660,00 in the country [27]. RI plays assumes a significant job and turns into an impetus for financial development in Malaysia with the commitment of 35\% of the country's Gross Domestic Product (GDP) while shares $58 \%$ of absolute work [28]. In Malaysia, RI can be grouped into four (4) categories, namely: (1) Electric Train Service (ETS), (2) Monorail, (3) Express Rail Link (ERL), and (4) Light Rapid Transit (LRT) [29]. The four main sectors are heavy rail service sectors [30]. The categories are based on daily usage in Malaysia that focuses on climate change as greener choice of transportation, urbanization and population growth, congestion that wastage of time and energy, and oil scarcity and price of energy [31].

RSC is one of the important elements in the public advancement plan that underlines on (1) Economic Transformation Program (ETP) centers around associating with Singapore through a high-speed rail system and building a coordinated metropolitan mass rapid transit system, (2) Government Transformation Program (GTP) center around improving metropolitan public vehicle by improving vehicle accessibility, improve reliability and journey times, improve accessibility and connectivity and regulatory restructuring, (3) $10^{\text {th }}$ Malaysia Plan (2011-2015) that RM 2.8 billion is distributed for improving the metropolitan public vehicle in the initial two years of the 1oth Malaysia Plan and (4) Industrial Master Plan 3 spotlight on National Industrial Development Plan on encouraging in general coordination's advancement just as creating rail freight service and focusing on Green Technology Policy and States Development Initiatives [32]. Therefore, RI needs a dynamic RSC model to implement the government agenda, where we have tabulated in Table 3. 
International Journal of Engineering Research and Technology. ISSN 0974-3154, Volume 13, Number 11 (2020), pp. $3927-3933$

(C) International Research Publication House. https://dx.doi.org/10.37624/IJERT/13.11.2020.3927-3933

Table 3. The Dynamic Railway Supply Chain Perspective

\begin{tabular}{|c|c|c|c|}
\hline Supplier Management & $\begin{array}{c}\text { Railway Supply Chain } \\
\text { Indicators }\end{array}$ & Business Architecture Model & Dynamic Perspective \\
\hline $\begin{array}{l}\text { Final integrator-complete } \\
\text { train suppliers }\end{array}$ & $\begin{array}{ll}\text { - } & \text { Industrial Builders } \\
\text { - } & \text { Train Builders } \\
\text { - } & \text { Coaches Builders } \\
\text { - } & \text { High-Speed Train } \\
& \text { Builders }\end{array}$ & $\begin{array}{c}\text { Entirely capable of autonomous action and decision, } \\
\text { where the system that completely replicates human } \\
\text { interactions. }\end{array}$ & $\begin{array}{c}\text { की } \\
\text { Artificial Intelligence } \\
\text { (Mimics human } \\
\text { intelligence) }\end{array}$ \\
\hline $\begin{array}{l}\text { Sub-systems train and } \\
\text { major systems integrators } \\
\text { suppliers }\end{array}$ & $\begin{array}{ll}- & \text { Rail Vehicle } \\
& \text { Accessibility } \\
& \text { Equipment } \\
\text { - } & \text { Rail Vehicle Body and } \\
& \text { Interior } \\
\text { - } & \text { Rail Mechatronics } \\
\text { - } & \text { Equipment } \\
\text { Rail Electrification } \\
\text { Equipment }\end{array}$ & $\begin{array}{l}\text { Interprets human behavior or communication that } \\
\text { comes to conclusions for judgment-based processes } \\
\text { and predictive decision-making suggestions. }\end{array}$ & $\begin{array}{l}\text { Cognitive Automation } \\
\text { (Mimics augments } \\
\text { human intelligence and } \\
\text { judgment) }\end{array}$ \\
\hline $\begin{array}{l}\text { Parts Manufacturers and } \\
\text { Components suppliers }\end{array}$ & $\begin{array}{ll}\text { - } & \text { Rolling Stocks } \\
\text { - } & \text { Rail Signaling and } \\
& \text { Communication } \\
\text { - } & \text { Rail Tracks } \\
& \text { Components and } \\
& \text { Equipment } \\
\text { - } & \text { Rail Electrification }\end{array}$ & $\begin{array}{l}\text { Faster processing time with higher volumes and } \\
\text { reduced errors through the rule-based process on } \\
\text { processing exceptions. }\end{array}$ & (Mimics human actions) \\
\hline
\end{tabular}

Table 3, indicates the dynamic RSC perspective in Artificial Intelligence (AI) that makes major strides in process areas for high complex activities and executives are exploring the potential to generate investment decisions, cognitive automation signifies boundary-based frameworks that learn and change after some time and robotics signify the rule-based through high-volume undertakings and industrial cycles that not need human judgment. BA is broadly viewed as the beginning stage for a cycle of the switch since it shows up the holes between the current circumstance and the ideal circumstance and encourages arrangement between industrial IS and industry objectives [33].

We believe that $76 \%$ of organizations over a wide scope of ventures will substantially transform their business within 3 years. Yet organization finds themselves stuck in an experimental model that limits their articulated vision and ambition through complexity technology processes. Moreover, the current issues and challenges in RSC focus on (1) Lack of shared trait on high life cycle uphold cost with foreign control and trade imbalance, (2) high dependency on the foreign supplier on low product localization and lack of product support, (3) deficiency of gifted or information workforce on in house preparing supplier and lack analysis skill in predictive maintenance, (4) absence of abilities to help item life cycle on the poor procurement process and lack system integration capabilities, (5) unclear policy and institutional framework on hold land for rail and absence of devoted rail motivating force and (6) insufficient rail infrastructure on passenger and freight sharing tracks and lack of intermodal and seamless connectivity [4], [32], [34].

Therefore, we need a dynamic RSC perspective that posits a key enabler to the national agenda by developing an RSC model in BA. A large portion of the administration plan is revolved around rail activity and less accentuation on building up the supporting business around the supply chain [35]. Thus, we need to initiate the framework procedures and an activity that intends to additionally build up the Malaysia RSC strategized decision-making process.

\section{CONCLUSION}

The Malaysian Government's future is on rail speculation by utilizing on rail venture that in the pipeline until 2030 and future. Therefore, the RI operation is a developing pattern through an extension plan of current organizations and locally operates to offer its service in all fragments of rail transportation. Disruptive digitalization is as of now changing the scene of numerous enterprises and their plans of action. Due to progressively digitalized cycles and exponential development of reasonable information, RSC is additionally affected by the fourth industrial revolution. Since RSC will go through an industry change, a business structure is important to comprehend which action is affected by a holistic administration point of view.

Hence, understanding the RSC indicators from design, manufacturing, and assembly will support the industry changes. Continuous improvement in industry performance needs a BA model as a strategic imperative in their performance. BA underpins the execution of normalized management policy appropriate to the use and development of IS and different assets. Once the BA instrument has been mapped with all the other rating and ranking systems, it will be evaluated and proposed improved RSC indicators. Therefore, we need a dynamic RSC perspective that posits a key enabler to the national agenda by developing an RSC model in BA. 


\section{ACKNOWLEDGEMENT}

The authors wanted to thank the reviewers and editor for their advice to sustain the norm of this paper. Our thanks are likewise to Universiti Teknikal Malaysia Melaka (UTeM) for the UTeM Zamalah Scheme for supporting and sponsorship this research work.

\section{REFERENCES}

[1] R. Hinkelmann, K., Gerber, A., Karagiannis, D., Thoenssen, B., Van der Merwe, A. and Woitsch, "A new paradigm for the continuous alignment of business and IT: Combining enterprise architecture modelling and enterprise ontology.," Comput. Ind., vol. 7, no. 9, pp. 77-86, 2016.

[2] M. Al-Kharusi, H., Miskon, S. and Bahari, "Factors Influencing the Engagement between Enterprise Architects and Stakeholders in Enterprise Architecture Development.," In PACIS, vol. 6, no. 1, p. 262, 2016.

[3] M. Jayakrishnan, A. K. Mohamad, and M. M. Yusof, "Information System for Integrative and Dynamic Railway Supply Chain Management," Int. J. Adv. Trends Comput. Sci. Eng., vol. 9, no. 2, pp. 2159-2167, 2020.

[4] W. Omar, “Transformation Plan 2015-2020," Dep. Stat. Malaysia, vol. 1, no. 1, p. 79, 2017.

[5] E. E. Chan, A.P.C., Darko, A. and Ameyaw, "Strategies for promoting green building technologies adoption in the construction industry-An international study.," Sustainability, vol. 9, no. 6, p. 969, 2017.

[6] A. Tim, Y., Pan, S.L., Bahri, S. and Fauzi, "Digitally enabled affordances for community-driven environmental movement in rural Malaysia.," Inf. Syst. J., vol. 28, no. 1, pp. 48-75, 2018.

[7] L. G. Cretu, Designing Enterprise Architecture Frameworks: Integrating Business Processes with IT Infrastructure. Apple Academic Press., 2016.

[8] G. Roelens, B., Steenacker, W. and Poels, "Realizing strategic fit within the business architecture: the design of a process-goal alignment modeling and analysis technique.," Softw. Syst. Model., pp. 1-32, 2017.

[9] J. Zdravkovic, J., Stirna, J. and Grabis, "A comparative analysis of using the capability notion for congruent business and information systems engineering.," Complex Syst. Informatics Model. Q., vol. 10, pp. 1-20, 2017.

[10] O. Benabdellah, A.C., Bouhaddou, I., Benghabrit, A. and Benghabrit, "A systematic review of design for $\mathrm{X}$ techniques from 1980 to 2018: concepts, applications, and perspectives.," Int. J. Adv. Manuf. Technol., pp. 130, 2019.

[11] M. Jayakrishnan, A. K. Mohamad, and A. Abdullah, “A Systematic Literature Review in Enterprise Architecture for Railway Supply Chain of Malaysia Transportation Industry," Int. J. Eng. Res. Technol., vol. 12, no. 12, pp. 2473-2478, 2019.
[12] M. Jayakrishnan, A. K. Mohamad, and M. M. Yusof, "Strategic Information System for Decision Making in Railway Supply Chain Management," Int. J. Adv. Trends Comput. Sci. Eng., vol. 9, no. 3, pp. 3988-3994, 2020.

[13] A. K. Mohamad, M. Jayakrishnan, and N. H. Nawi, "Employ Twitter Data to Perform Sentiment Analysis in the Malay Language," Int. J. Adv. Trends Comput. Sci. Eng., vol. 9, no. 2, pp. 1404-1412, 2020.

[14] C. B. Whittle, R. and Myrick, Enterprise business architecture: The formal link between strategy and results. CRC Press., 2016.

[15] M. Borthwick, Pacific century: The emergence of modern Pacific Asia. Routledge., 2018.

[16] M. Jayakrishnan, A. K. Mohamad, and A. Abdullah, "Enterprise Architecture Embrace Digital Technology in Malaysian Transportation Industry," Int. J. Eng. Adv. Technol., vol. 8, no. 4, pp. 852-859, 2019.

[17] M. Madah Marzuki and E. A. Abdul Wahab, "International financial reporting standards and conservatism in the Association of Southeast Asian Nations countries," Asian Rev. Account., vol. 26, no. 4, pp. 487-510, Dec. 2018.

[18] A. Aceto, G., Persico, V. and Pescapé, "The role of Information and Communication Technologies in healthcare: taxonomies, perspectives, and challenges.," J. Netw. Comput. Appl., vol. 10, no. 7, pp. 125-154, 2018.

[19] M. Jayakrishnan, A. K. Mohamad, and A. Abdullah, "Digitalization Approach Through An Enterprise Architecture For Malaysia Transportation Industry," Int. J. Civ. Eng. Technol., vol. 9, no. 13, pp. 834-839, 2018.

[20] S. Dang, D.D. and Pekkola, Problems of enterprise architecture adoption in the public sector: root causes and some solutions. Springer, Cham., 2017.

[21] M. Jayakrishnan, A. K. Mohamad, and A. Abdullah, "Journey of an Enterprise Architecture Development Approach in Malaysian Transportation Industry," Int. J. Eng. Adv. Technol., vol. 8, no. 4, pp. 765-774, 2019.

[22] Marcia J Bates, "Information search tactics," J. Assoc. Inf. Sci. Technol., vol. 30, no. 4, pp. 205-214, 1979.

[23] R. A. Hirschheim, "Information Systems Epistemology: An Historical Perspective," Inf. Syst. Res. Issues, methods Pract. Guidel., pp. 9-33, 1992.

[24] S. Petter, W. DeLone, and E. McLean, "Measuring information systems success: Models, dimensions, measures, and interrelationships," Eur. J. Inf. Syst., vol. 17, no. 3, pp. 236-263, 2008.

[25] B. Kitchenham, O. P. Brereton, D. Budgen, M. Turner, J. Bailey, and S. Linkman, "Systematic literature reviews in software engineering-a systematic literature review," Inf. Softw. Technol., vol. 51, no. 1, pp. 7-15, 2009.

[26] S. Sorooshian, "Information Technology for Supply Chain Management: Literature Review," Int. J. Adv. Trends Comput. Sci. Eng., vol. 9, no. 1, pp. 80-86, Feb. 2020. 
[27] I. F. M. Ainul, N.N.K.N.M., Ahmad, A.C., Derus, M.M. and Kamar, "Determination of Direct to Indirect Accident Cost Ratio for Railway Construction Project.," in In MATEC Web of Conferences, 2019, vol. 266, p. 03009 .

[28] J. J. Palacios, Multinational corporations and technology transfer in Penang and Guadalajara. Routledge., 2018.

[29] M. S. Shahidan, S., Hannan, N.I.R.R., Maarof, M.Z.M., Leman, A.S. and Senin, "A comprehensive review on the effectiveness of existing noise barriers commonly used in the railway industry.," in In MATEC Web of Conferences, 2017, vol. 87, p. 01007.

[30] D. Sa'adin, S.B., Kaewunruen, S. and Jaroszweski, "Operational readiness for climate change of Malaysia high-speed rail.," Proc. Inst. Civ. Eng. Transp, vol. 169, no. 5, pp. 308-320, 2016.

[31] O. García-Olivares, A., Solé, J. and Osychenko, "Transportation in a 100\% renewable energy system.," Energy Convers. Manag., vol. 158, pp. 266-285, 2018.

[32] MOT, “Transport Statistics Malaysia 2017," Minist. Transp. Malaysia, pp. 1-117, 2017.

[33] G. Zacharewicz, G., Diallo, S., Ducq, Y., Agostinho, C., Jardim-Goncalves, R., Bazoun, H., Wang, Z. and Doumeingts, "Model-based approaches for interoperability of next generation enterprise information systems: state of the art and future challenges.," Inf. Syst. E-bus. Manag., vol. 15, no. 2, pp. 229-256, 2017.

[34] Ismail Ibrahim, Blueprint 2010 -2030 for Iskandar Malaysia Transportation. Kuala Lumpur: Iskandar Regional Development Authority (IRDA), 2011.

[35] M. I. M. Aziz, S.A., Kassim, R. and Masirin, "Railway Development and the Impact to Malaysian Economy.," Jour Adv Res. Dyn. Control Syst., vol. 10, no. 6, 2018. 